\title{
COREESPONDENCE.
}

\section{SUARDALAN, GLENELG.}

Srr,-At a recent meeting of the Geological Society, after the reading of Mr. G. Barrow's communication on the supposed Silurian Rocks of Forfarshire, Sir A. Geikie alluded to similar rocks which have been found elsewhere along the Highland Border, and (as reported) be gives to me the credit of having found these rocks in the district lying between Loch Lomond and Callander.

The credit of this discovery does not belong to me, but to my friend and former colleague, Mr. J. R. Dakyns. I merely completed the mapping of the rocks alluded to after Mr. Dakyns left Scotland.

GleNela, June 19, 1901.

C. T. Clovgh.

\section{OBITUARY. \\ RICHARD HOWSE, M.A. \\ BORN 1821. \\ DIED 1901.}

Alu visitors to Newcastle-upon-Tyne on the occasion of the last meeting of the British Association there, in 1889, remember the large and, in some respects, unique collections displayed in the fine and spacious new building known as the "Hancock Museum." Older visitors will also remember the same collections housed, or rather hidden away, in the cramped and crowded old Natural History Museum at the other end of the city. All must have carried away a pleasing recollection of the handsome, dignified and, latterly, venerable naturalist who was the loving and somewhat jealous guardian of the scientific treasures in both places. Mr. Richard Howse had for so many years been identified with these collections, had for so long watched over, exhibited, and described their rarities, that he had come to be regarded, as it were, as the one living being amongst the multitudinous dead things around him, and it is difficult to think of them bereft of his animating presence. $\mathrm{Mr}$. Howse was no ordinary Curator. Born in Oxfordshire in 1821, much of his boyhood was spent in collecting the land and fresh-water shells, the birds and eggs, and especially the fossils which abound round Thame, his native place. At a very early age he came and established himself as a schoolmaster at South Shields, and from that time-for some sixty years-his residence in the North of England was unbroken. From the moment of his arrival on Tyneside he made the study of the natural objects of the land and sea about him the main purpose of his life. To his extraordinary activity as an observer and collector all the scientific publications of the North bear witness. His name is to be found repeatedly quoted in-I think I may say-every one of the many lists of plants, animals, or fossils which make the 'Transactions of the Newcastle and Berwickshire Societies so valuable as sources of accurate reference. He was fortunate in coming at a time when 
Dr. Johnston of Berwick, Albany Hancock, and Joshua Alder were working out the Invertebrates of the North-East coast, when the materials for Baker's "Flora" were being accumulated by Watson, Bowman, Wailes, and Oliver, when George Tate of Alnwick was classifying the Lower Carboniferous rocks of North Northumberland, and William Hutton, with Lindley and Witham, was bringing out his Fossil Flora, when King was beginning his Permian work, when Bold was cataloguing the insects of the district, and when John Hancock and Hewitson were studying its birds and their eggs. Mr. Howse was a fellow-worker with all these men and, later, with Atthey, Norman, Horlge, Embleton, Kirkby, Duff, Dinning, the two Bradys, and others of whom some are still with us. $\mathrm{He}$ botanized, geologized, dredged, collected fossils, and all things-in a universal way almost appalling to a modern specialist. Moreover, in geology he was by no means a mere collector, for he did a considerable amount of original mapping-as in Weardale and in Redesdale-long before the Geological Survey had entered upon the ground. Chiefly in order to be nearer the Museum and the Library of the Literary and Philosophical Society he after a few years removed from Shields to Newcastle, where he opened another private school, in which many of the present leading men of the North were educated-including, I believe, the actual senior Member for the city. When Dr. King left Newcastle Mr. Howse succeeded to the Curatorship of the Museum, still keeping school, however, and devoting only what time he could spare to the collections. But this was for a short period only, and in the seventies he was able to relinquish teaching and give his whole time to the Museum. The removal of the specimens, many of which had scarcely been unpacked before for lack of room, and their entire rearrangement in the Hancock Museum (largely due to the liberality of the late Lord Armstrong, and opened by the Prince of Wales in 1884), were carried out by him with the assistance of his well-known and capable lieutenant, Mr. Joseph Wright. Curating was not his only work: he was ex-officio editor of the joint Transactions of the Natural History Society and Field Club, and also for many years one of the Honorary Secretaries of the latter.

Mr. Howse's publications were far too numerous to be fully detailed here. Amongst the most important must be mentioned an armirable Synopsis of the Geology of Northumberland and Durham, written jointly with Mr. Kirkby for the use of the British Association in 1863; a Catalogue of Permian Fossils, with a later Supplement, which gave rise to a lively priority dispute with Dr. King, whose own "Catalogue" appeared almost on the same day as Mr. Howse's ; a Catalogue of the Hutton Collection of Fossil Plants; one of the local Carboniferous Fossils in the Museum; another of the Fishes, etc.; and some joint palæontological papers with Albany Hancock and others. Of purely geological memoirs two-one on the Boundary between the Millstone Grit and the Carboniferous Limestone Series and the other on the Divisions of the Drift in the North of England-were of special value. 
Mr. Howse's writings on geology and palæontology, howerer, do not represent a tithe of the results of his labours. He overflowed with information, but was slow to publish. Much of his knowledge has died with him, since he does not appear to have left any manuscript notes of consequence. Many undescribed specimens remain in safe keeping which it had been his intention to describe, and which are still, of course, available for study.

Mr. Howse was essentially a practical and original worker, and a willing helper to other workers. His kindness to all in whom he saw even the slightest trace of the great love of Nature which was his own most striking characteristic was unfailing. Coupled with this was a sensitiveness which sometimes led him into controversies such as that with Professor King already referred to, and a constitutional shyness which prevented him from taking any prominent part on public occasions. It is pleasant to think that notwithstanding this he was gratified towards the close of his active and useful life by the award of an honorary degree by the University of Durham.

G. A. Lebour.

\section{JOSEPH LE CONTE.}

Bonn Feb. 26, 1823.

Died 1901.

Joseph Le Conte was born in Liberty Co., Georgia, Feb. 26th, 1823. He was a descendant of a French Huguenot who towards the end of the seventeenth century emigrated to New Rochelle, New York. His grandfather removed to Georgia before the revolution. His father, Louis Le Conte, was a graduate of Columbia College. Joseph graduated at Franklin College, Georgia, in 1841, and at the New York College of Physicians and Surgeons in 1845. After practising for a short time at Macon, Georgia, he went to Cambridge, Mass., where he studied under the elder Agassiz, whom he accompanied in 1851 on an exploring expedition to Florida. After graduating at the Lawrence Scientific School in Cambridge he was for a few years Professor of Natural History and Geology in Franklin College, and from 1856 to 1869 Professor of Chemistry and Geology in South Carolina College. In 1869 he was appointed Professor of Geology and Natural History in the University of California, a post that he held from that time until his death. In 1892 he was President of the American Association for the Advancement of Science, the meeting being held that year at Rochester, New York. He wrote a series of papers on Monocular and Binocular Vision, but his more important works deal with Natural History and Geology. In 1874 he issued his book on "Religion and Science; a series of Sunday lectures on the relation of natural and revealed religion," and in 1888 his work on "Evolution: its history, its evidences, and its relations to Religious thought." He published several papers on Physical Geology; of these his essay entitled "A theory of the formation of the great features of the earth's surface" deserves to be specially mentioned. His "Elements of Geology" appeared in 1878, and a revised and enlarged edition in 1882 . 